\title{
Kualitas Pentatahan Relief Di Kompleks Candi Prambanan
}

\section{Hari Lelono}

Keywords: sculpting technique, meaning, technology, prambanan, hindu-buddha

\section{How to Cite:}

Lelono, H. (1996). Kualitas Pentatahan Relief Di Kompleks Candi Prambanan. Berkala Arkeologi, 16(2), 50-61. https://doi.org/10.30883/jba.v16i2.753

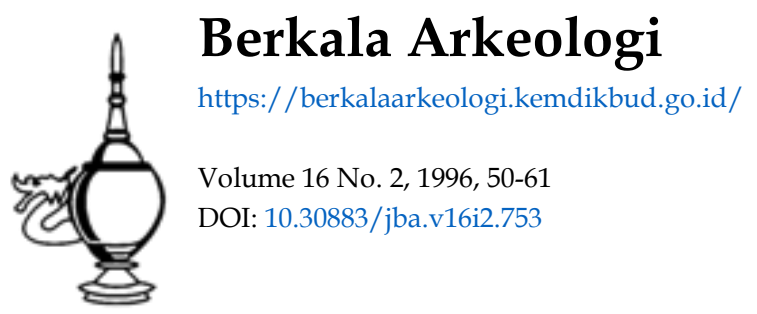

\section{c) (1) (5)}

This work is licensed under a Creative Commons Attribution-NonCommercial-ShareAlike 4.0 International License. 


\title{
KUALITAS PENTATAHAN RELIEF \\ DI KOMPLEKS CANDI PRAMBANAN
}

\author{
T.M. Hari Lelono \\ (Balai Arkeologi Yogyakarta)
}

\section{Latar Belakang Masalah}

Studi percandian sangat menarik dan telah banyak dikaji oleh para ahli, sehingga dapat memberikan kontribusi yang sangat berharga bagi pembangunan negara, khususnya sektor kepariwisataan. Namun, studi relief belum banyak dilakukan oleh para pemerhati seni relief, khususnya relief cerita yang dipahatkan pada candi. Padahal melalui relief dapat diungkap kehidupan masyarakat Jawa kuno masa lalu, baik aspek sosial. politik, ekonomi, dan seni.

Dalam catatan sejarah diketahui bahwa dinasti Mataram kuno tumbuh dan berkembang dengan pesat di daerah Jawa Tengah pada kurun waktu abad VII -- X M, yang kemudian masa perkembangan berikutnya dilanjutkan ke Jawa Timur abad ke $X$-- XV $M$, antara lain akibat adanya bençana alarn. Salah satu pendapat Yzerman mengatakan bahwa perpindahan tersebut karena bencana alam yang dahsyat. Gunug api meletus merupakan pertanda kemarahan para dewa sehingga memaksa penduduk untuk pindah. J.G.de Casparis memperkirakan perpindahan tersebut disebabkan keadaan ekonomi dan politik (Maulana, 1996:2).

Kebesaran dan kekuasaan Mataram kuno di wujudkan dalam bentuk bangunan-bangunan monumental berupa candi-candi yang dibangun dengan megahnya, serta melingkupi wilayah yang sangat luas, dail Gatalan tinggi Dieng, sekitar pegunungan Sindoro-Sumbing. Merapi, dan Lawu. Diantara sekian banyak candi yang dibangun terdapat dua buah candi yang besar dan anggun, yakni candi Borobudur dan Candi Prambanan (Loro Jonggrang).

Pada masa Mataram kuno agama yang dianut dan berkembang pesat pada waktu itu adalah agama Hindu dan Buddha. Dua agama tersebut merupakan agama 'istana' yang dalam perkebangannya diikuti oleh seluruh warga masyarakat Jawa kuno pada waktu itu. Bukti kebesaran agama tersebut tercermin di dalam pembangunan candicandi, dalam beberapa kasus pembangunan candi selalu terdapat sinkritisme, yakni percampuran dua agama (Haryono, 1997:4), dalam hal ini agama Hindu dan Buddha. 


\section{Masalah}

Candi Loro Jonggrang merupakan kelompok candi Hindu yang dibangun pada masa dinasti Sanjaya, pada kurang lebih abad ke IX M. Hal tersebut dibuktikan dengan diketemukannya prasasti Çiwagrha berangka tahun 856 Masehi. Pada kompleks candi ini terdapat tiga buah candi utama, yang masing-masing mempunyai candi wahana. Ketiga candi tersebut adalah Candi Çiwa (di tengah), Candi Brahma (sisi selatan), dan Candi Wisnu (sisi Utara).

Soekmono dalam disertasinya: Candi, Fungsi dan Pengertiannya (1974) telah menafsirkan fungsi dan makna simbolik candi sebagai kuil, bukan sebagai makam. Kajiannya bertitik tolak dari Archaeological record yaitu peripih, arca, relief cerita (prasawya, pradaksina), berdasarkan penentuan arah pembacaan, arah hadap candi, dan sifat keagamaan candi Hindu Buddha (Rangkuti, 1995:2-3).

Langgam arsitektur candi Jawa Tengah-an cenderung ramping apabila dibandingkan dengan langgam Jawa Timur-an yang cenderung tambun. Terlepas dari konteks arsitektur tersebut, pada setiap bangunan candi, utamanya candi-candi istana pada bagian kaki dan badan candi terdapat panil-panil berbentuk segi empat panjang dan dihiasi dengan hiasan relief. Relief biasanya berbentuk tatahan/pahatan yang menggambarkan/mengkisahkan suatu cerita tertentu, berkaitan dengan agama, ajaran moral, hukum-hukum (karma), dan contoh tentang 'kebaikan' dan 'kejahatan'. Sarana relief dapat menggunakan bahan kayu dan dalam konteks candi digunakan dari bahan batu. Di dalam satu panil, kadang terdapat satu atau lebih adegan cerita.

Tidak terlepas dari kitab Silpasastra, khususnya relief cerita mengandung makna dan tujuan yang berkaitan dengan religi dan fungsi komunikatif. Fungsi religi berkaitan dengan kepercayaan dan agama yang ada pada masyarakat Jawa kuno. Sedangkan fungsi komunikatif untuk meyebar-luaskan ajaran agama kepada masyarakat secara luas. Berkaitan dengan fungsi-fungsi tersebut, seni relief dikerjakan seindah dan sebaik mungkin, untuk dipersembahkan kepada para dewa/raja. Menarik perhatian dalam kasus seni relief dari ketiga candi adalah: Mengapa relief Ramayana pada Candi Çiwa (tengah) paling baik ditinjau dari segi pentatahan/pahatannya?

Pada kesempatan ini akan sedikit mengungkap seni relief dari hasil pengamatan yang dilakukan pada tahun 1995 di Candi Prambanan, D.I.

Dalam konteks fungsi candi, reliaf sebagai elemen pelengkap, dalam memberikan contoh-contoh ajaran dan perjalanan tokoh-tokoh dewa dalam manifestasimya sebagai raja. 
Yogyakarta. Pokok masalah yang ditelaah adalah perbedaan kualitas pemahatan relief candi. Studi yang dilakukan merupakan langkah awal untuk ditindaklanjuti secara lebih seksama pada masa mendatang

\section{Pembahasan}

Candi Prambanan yang terdiri dari tiga buah candi utama (Ciwa, Brahma, dan Wisnu), masing masing dihiasi dengan relief cerita Ramayana dan Kresnayana. Candi Ciwa yang terbesar dari dua candi lainnya mengandung panil cerita sebanyak 24 buah, Candi Brahma dan Wisnu masing-masing 30 buah panel cerita.

\subsection{Candi Ciwa}

Candi Ciwa berukuran $34 \times 34 \mathrm{~m}^{2}$ dan tinggi 47 meter, secara keseluruhan memperlihatkan keserasian dalam ukuran dan bagianbagian candi, perimbangan antara bingkai-bingkai tegak (vertikal) dan bingkai-bingkai datar (horisontal), sangat serasi dtitambah dengan berbagai ragam hias untuk mempertinggi keindahan candi.

Seperti lazimnya candi-candi di Jawa, Candi Ciwa mempunyai tiga bagian, yaitu kaki candi, tubuh dan atap candi, dan secara berturut-turut ketiganya melambangkan dunia bawah bhurloka, dunia tengah bhurwaloka, dan dunia atas swarloka (Maulana, 1996:10).

Cerita Ramayana dipahatkan pada Candi Çiwa yang dilanjutkan ke Candi Brahma, sedangkan Candi Wisnu hanya memuat cerita Kresnayana. Masing-masing panil terdiri dari satu adegan cerita atau lebih, sesuai dengan panjang atau tidaknya sebuah panil. Kadangkala ditentukan oleh' luas atau sempitnya bidang untuk menempatkan sebuah panil. Sebagai contoh, panil yang panjang di Candi Çiwa adalah Panil bernomor 13 pada sisi timur (arah hadap panil timur) berukuran panjang $505 \mathrm{~cm} \times$ tinggi $80 \mathrm{~cm}$, terdiri atas empat buah adegan cerita. Isi cerita dari panil tersebut, mengisahkan bahwa Rama dan Laksmana bertempur melawan raksasa Kabandha Mereka berhasil mengalahkan dan mengembalikan kewujudnya yang semula. Kabandha adalah inkarnasi dewa yang dikutuk oleh Dewa Çiwa dan dihukum untuk hidup sebagai mahiuk yang jelek.

Bahan candi dari batu andesit, khususnya pada candi Çiwa bila diamati secara seksama rata-rata proses silika batuan lebih tinggi/kompak (halus) dibandingkan dengan dua candi di sisi kiri dan kanannya. Hal tersebut sangat menarik perhatian karena suatu kebetulan atau ada unsur kesengajaan yang berkaitan dengan konsepkonsep religi/agama pada masa lalu. Selain bahan batuan yang lebih kompak/halus, dalam proses pengerjaan/pentatahan para senimannya 
mengerjakan dengan sempurna dan sangat indah dipandang. Hal tersebut akan semakin jelas apabila diamati lebih seksama detail yang ditatahkan pada wujud manusia maupun pakaian yang dikenakan khususnya detail pada bagian kain mencakup asesoris yang melengkapinya. Sebagai contoh lipatan kain yang dikenakan oleh Rama dapat dilihat dengan jelas sampai ke lipatan-lipatan kecil pada wiron.

Teknik pemahatan pada panel sangat bagus dan lengkap, tentunya hanya dapat dikerjakan oleh para seniman yang handal. Hal tersebut dapat dilihat pada panel-panel yang dijadikan sampel, seluruhnya berjumlah dua belas buah (lihat tabel 1).

\section{Tabel 1, Relief Ramayana Candi Çiwa}

\begin{tabular}{|c|c|c|c|c|}
\hline No. & $\begin{array}{c}\text { Adegan Cerita } \\
\text { (ukuran/cm) }\end{array}$ & $\begin{array}{l}\text { No. } \\
\text { Panil }\end{array}$ & $\begin{array}{l}\text { Posisi } \\
\text { Hadap }\end{array}$ & Deskripsi \\
\hline $\begin{array}{l}\text { A. } \\
01\end{array}$ & $\begin{array}{l}\text { Ramayana } \\
\text { idem (80 X 208) }\end{array}$ & 2 & Ulara & $\begin{array}{l}\text { Darja Dasarata kedatangan tamu pen- } \\
\text { deta bernama Wismamitra, minta to } \\
\text { long kepada Rama untuk membunuh } \\
\text { raksasa yang menganggu pertapaan- } \\
\text { mya. }\end{array}$ \\
\hline 02. & idem $(78 \times 194)$ & 3 & barat & $\begin{array}{l}\text { Rama dan Laksmana dalam perjalan- } \\
\text { an menuju pertapaan Wismamitra, di- } \\
\text { gangou olek Raseksi Tataka. Rama } \\
\text { membunuhnya di hutan. }\end{array}$ \\
\hline 03. & idem $(80 \times 200)$ & $5 a$ & barat & $\begin{array}{l}\text { Di Kerajaan Mantilireja, memerintah } \\
\text { Raja Janaka. Mengadakan sayemba- } \\
\text { ra: barangsiapa dapat menarik dan } \\
\text { mematahican busur, akan dikawinkan } \\
\text { dengan puterinya bernama Sinta. Ra- } \\
\text { ma thut ambil bagian dan memenang- } \\
\text { kan. }\end{array}$ \\
\hline 04 & idem $(80 \times 520)$ & $6 \mathrm{c}$ & Utara & $\begin{array}{l}\text { Raja Dasarata merasa telah lanjut } \\
\text { usia, Ingin mewariskan tahta kepada } \\
\text { Rama, Raja dan permaisurinya para } \\
\text { pembantunya sedang mempersiapkan } \\
\text { pesta penobatan }\end{array}$ \\
\hline 05 & idem $(80 \times 500)$ & $7 a$ & utara & $\begin{array}{l}\text { Penobatan Rama sebagai putera } \\
\text { mahkota, dilakukan oleh seorang pen- } \\
\text { deta. Di luar istana rakyat merayakan } \\
\text { penobatan tersebut. }\end{array}$ \\
\hline
\end{tabular}




\begin{tabular}{|c|c|c|c|c|}
\hline 06 & idem $(80 \times 195)$ & 8 & timur & $\begin{array}{l}\text { Tidak lama kemudian, Raja Dasarata } \\
\text { wafat karena dukacita; jenazahnya di- } \\
\text { perabukan. Para brahmana dan per- } \\
\text { maisuri Kausalya membagi-bagikan } \\
\text { dana kepada rakyat Ayodya. }\end{array}$ \\
\hline 07. & Idem $(80 \times 505)$ & $13 \mathrm{c}$ & trmur & $\begin{array}{l}\text { Rama dan Laksmana bertempur me- } \\
\text { lawan raksasa Kabandha. Mereka } \\
\text { berhasil mengalahkannya dan me- } \\
\text { ngembafikan kepada mujudnya yang } \\
\text { semula. Kabandha adalah inkamesi } \\
\text { dewa yang dikutuk oleh Dewa Ciwa } \\
\text { dan dihukum untuk hidup sebagai } \\
\text { mahluk yang jelek. }\end{array}$ \\
\hline 08 & idem $(80 \times 193)$ & 14 & selatan & $\begin{array}{l}\text { Rama oan Laksmana bertemu dengan } \\
\text { seekor buaya yang sebenarnya inkar- } \\
\text { nasi seorang bidadari yang terkena } \\
\text { kutukan oleh Dewa. Setelah terkena } \\
\text { panah Rama, berubah ke dalam wh } \\
\text { judnya yang semula dan terbang ke } \\
\text { surga. }\end{array}$ \\
\hline 09. & idem $(80 \times 195)$ & 15 & timur & $\begin{array}{l}\text { Rama dan Laksmana bertemu dengan } \\
\text { Hanoman, seekor kera putih. Dia me- } \\
\text { mohon kepada mereka untuk mene- } \\
\text { mui Sugrtwe, raja kera. }\end{array}$ \\
\hline 10 & idem $(80 \times 495)$ & $18 \mathrm{c}$ & Selatan & $\begin{array}{l}\text { Sugriwa mongusulkan kepada Rama } \\
\text { agar mau mengirim utusan, yaitu Ha- } \\
\text { noman, untuk mencari Sinta di Aleng- } \\
\text { ka }\end{array}$ \\
\hline 11. & idem $(82 \times 195)$ & $20 a$ & barat & $\begin{array}{l}\text { Hanoman berada di dalam taman is } \\
\text { tana Rawana, tempat Sinta disekap. } \\
\text { Dia mengintlp Sinta dari atas pohon } \\
\text { Sinta sedang duduk ditaman ditemani } \\
\text { oieh Trjata, keponakan Rawana. }\end{array}$ \\
\hline 12. & idem $(80 \times 195)$ & 21 & selatan & $\begin{array}{l}\text { Kedatangan Hanoman diketahui para } \\
\text { pengawal, dan ditangkap. Dia dikat } \\
\text { dengan tali dan okormya dibakar, } \\
\text { Tetapi dapat melepaskan diri, dia } \\
\text { melompat ke atas atap sambil } \\
\text { membakar. Dalam waktu sekejap } \\
\text { eeluruh kota Alengka terbakar }\end{array}$ \\
\hline
\end{tabular}

Diacu dari LHPA 1995. T.M. Hari Lelono 
Dua unsur (tokoh/figur dan asesoris) dalam lukısan dinding dibuat secara lengkap dan jelas, sehingga pada bagian-bagian kecil pun tampak ditonjolkan dan tidak ada yang dilewatkan. Khususnya pada Candi Ciwa kedua hal sangat diperhatikan, sehingga dapat diasumsikan bahwa dikerjakan oleh seniman yang profesional.

\subsection{Candi Brahma Dan Wisnu}

Candi dengan luas dasarnya $20 \times 20$ meter persegi dan tinggi 37 meter, terdapat satu ruangan dengan arca Brahma berkepala empat dan berlengan empat. Dasar kaki candi dikelilingi selasar yang dibatasi pagar langkan. Pada dinding bagian dalam terdapat 30 buah panel relief lanjutan dari cerita Ramayana. Cerita Ramayana di sini dimulai dari adegan Rama, Laksamana, Wismanitra dan Sugriwa berunding untuk mengatur siasat perang di Negeri Alengka dan diakhiri pada panel ke 30, yang merupakan adegan Sinta ditelan bumi ketika akan membuktikan kesuciannya, Rama sangat menyesal tetapi tidak dapat berbuat apa-apa (Murtjipto, 1991)

Bahan candi menggunakan batu andesit, namun batu yang digunakan lebih kasar, karena butiran partikel batuan lebih besas dibandingkan dengan candi Çiwa. Mungkin sumber batuan pada candi tersebut diambil dari daerah yang berbeda, atau sudah diseleksi atau disortir untuk pembangunan candi utama.

Dari segi pemahat relief, hasil pahatannya tidak seindah dan tidak sedetail dibandingkan dengan Candi Çiwa. Sebagai contoh pada panel bernomor 20 arah hadap selatan berukuran tinggi $76 \mathrm{~cm}$ panjang $102 \mathrm{~cm}$. Menggambarkan adegan Dewi Sinta duduk bersimpuh dan bersedih dihadapan seorang pendeta Mpu Walmiki setelah berhasil dibebaskan Rama. Pada panel tersebut, figur atau tokoh yang digambarkan kelihatan kaku, utamanya pada bagian kaki dan tangan lebih besar dibandingkan dengan ukuran tubuhnya.

Tatahan bagian tangan dan kaki Candi Brahma dan Wisnu cenderung lebih besar, sehingga ada kesan lebih gemuk dan kurang "hidup". Asesoris tidak ditatah secara lengkap, yang digambarkan hanya pada bagian-bagian utama, sedangkan bagian yang kurang penting misainya lipatan-lipatan kecil pada wiron tidak digambarkan. 
Tabel 2 Relief Ramayana Candi Brahma

\begin{tabular}{|c|c|c|c|c|}
\hline No. & $\begin{array}{c}\text { Adegan Cerita } \\
\text { (ukuran/cm) }\end{array}$ & $\begin{array}{c}\text { No. } \\
\text { Panil }\end{array}$ & $\begin{array}{l}\text { Posisi } \\
\text { Hadap }\end{array}$ & \multicolumn{1}{|c|}{ Diskripsi } \\
01. & $\begin{array}{l}\text { Ramayana } \\
\text { idem }(76 \times 102)\end{array}$ & 20 & selatan & $\begin{array}{l}\text { Dewi Sinta duduk bersimpuh } \\
\text { dihadapan seorang pertapa, setelah } \\
\text { berhasil dibebaskan oleh Rama } \\
\text { Adegan para brahmana sedang } \\
\text { bersuka cita atas kemenangan Prabu } \\
\text { Rama dalarn perang mengalahkan } \\
\text { angkara murka di muka bumi }\end{array}$ \\
\hline
\end{tabular}

Diacu dari LHPA 1995 T.M Hari Lelono

Candi Wisnu dipandang dari segi arsitektural, ukuran, bentuk, bahan dan luasnya, sama dengan Candi Brahma. Pada dinding pagar langkan bagian dalam juga terdapat 30 buah panel relief cerita Kresnayana. Sesuai dengan fungsinya sebagai tempat pemujaan Dewa Wisnu, relief cerita yang dipahatkan menggambarkan adegan kehidupan pada waktu kecil sampai dewasa Dewa Wisnu. Wisnu dikenal dan dipuja sebagai dewa penyelamat dan pemelihara dunia.

Teknik pentatahan dan penggambaran figur dan tokoh-tokohnya sama dengan candi Brahma, tidak seindah Candi Çiwa. Hal tersebut dapat dilihat pada sampel yang diambil sebanyak lima buah, lihat tabel 3 berikut ini:

Tabel 3, Relief Kresnayana Candi Wisnu

\begin{tabular}{|c|c|c|c|c|}
\hline No. & $\begin{array}{l}\text { Adegan Cerita } \\
\text { (ukuran/cm) }\end{array}$ & $\begin{array}{l}\text { No. } \\
\text { Panil }\end{array}$ & $\begin{array}{l}\text { Poslsi } \\
\text { Hadap }\end{array}$ & Deskripsi \\
\hline 01. & $\begin{array}{l}\text { Kresnayana } \\
\text { idem }(82 \times 96)\end{array}$ & 5 & barat & $\begin{array}{l}\text { Masa kecil Kresna dan Balarama se- } \\
\text { dang memperhatikan seorang ibu me- } \\
\text { numbuk padi. ? }\end{array}$ \\
\hline 02. & idern $(76 \times 180)$ & 8 & vtara & $\begin{array}{l}\text { Adegan Krena sedang membunulh se- } \\
\text { okor ular dengan merobek bagian mu } \\
\text { lutnya }\end{array}$ \\
\hline 03 & idem $(76 \times 95)$ & 10 & timur & $\begin{array}{l}\text { Krena di masa kecil adalah seorang } \\
\text { anak yang nakal, ia sedang menjung } \\
\text { kirkan seorang tua. }\end{array}$ \\
\hline 04. & idem $(76 \times 85)$ & 12 & timur & $\begin{array}{l}\text { Kresna menggoda seorang raksasa, } \\
\text { di dekat sebuah taman di bawah po- }\end{array}$ \\
\hline
\end{tabular}




\begin{tabular}{|l|l|l|l|l|}
\hline 05 & $\operatorname{idem}(75 \times 77)$ & 16 & tirmur & $\begin{array}{l}\text { hon besar. ?? } \\
\text { Kresna duduk dalam balai-balai dida- } \\
\text { tangi oleh dua orang pendeta dengan } \\
\text { pengitartmya. Terdapat seorang abdi } \\
\text { wanita membawa kampilislepet }\end{array}$ \\
\hline
\end{tabular}

Diacu dari LHPA 1995. T.M. Hari Lelono

Panel nomor 16 arah hadap timur, dengan ukuran tinggi $75 \mathrm{~cm}$ dan panjang $77 \mathrm{~cm}$. Dalam adegan dilukiskan Rama sedang duduk dalam balai-balai dan didatangı oleh dua orang pendeta dengan pengikutnya Kualitas pentatahan tidak sebagus dibandingkan dengan Candi Ciwa, apakah 'peran' Candi Wisnu dianggap kurang penting dibandingkan dengan Candi Çiwa?

Oleh karena itu, dari ketiga tatahan relief candi dapat dibedakan menjadi dua yakni:

a. Penggambaran tokoh/figur

Dipahatkan oleh seniman secara jelas dan perbandingan anatomi tubuh cenderung proposional dan dinamis. Bagian tangan dan kaki digambarkan dengan 'ramping'. Sehingga pahatan tersebut ada kesan baik dan 'hidup' bila dilihat dari kejauhan.

b. Asesoris

Asesoris adalah segala sesuatu yang melengkapi/menutup anggota tubuh. Dalam hal ini, adalah mahkota, subang, kalung, gelang, sabuk (ikat pinggang/badong), jubah, dan kain bawah (ada yang panjang dan pendek) termasuk di dalamnya lipatan-lipatan kecil yang biasanya ada dalam wiron

\section{Penutup}

Dari serangkaian hasil pengamatan yang dilakukan pada tahun 1995 - terhadap teknik pentatahan (seni relief). terdapat variasi dari segi pentatahan. Vanasi tersebut terletak pada penggambaran figur dan tokoh tertentu, serta asesoris yang melengkapinya. Oleh karena itu, berdasarkan pengamatan yang ditekankan pada segi keindahan pentatahan relief di Candi Prambanan dikerjakan oleh seniman, paling tidak dapat dibedakan secara garis besar menjadi dua kelompok.

41. Kelompok pertama Candi Çiwa, merupakan seniman pemahat yang profesional Dibuktikan pada hasil tatahannya lengkap dan sangat detail pada bagian asesoris maupun bentuk anotomi figur/tokoh tertentu 
42 Kelompok kedua Candi Brahma dan Wisnu, merupakan seniman setingkat di bawah yang pertama. Bukti dalam pentatahan tokoh maupun asesoris yang melengkapi tidak selengkap dan sedetail pada kelompok pertama

Adanya dua perbedaan tersebut, dapat ditarik hipotesis bahwa, masa pendirian candi relatif memerlukan waktu yang lama. Semua candi, baik yang besar maupun yang kecil dibangun dengan bentuk dan perhiasan yang sama. Dan perlu diulangi lagi bahwa yang mengerjakan bukannya satu orang saja tetapi beratus-ratus pemahat yang bekerja bersamaan (Koesnoen, 1971: 62-63)

Berdasarkan pada kualitas pemahatan dimungkinkan adanya pembagian kelompok seniman pahat Kelompok Candi Ciwa dikerjakan oleh tim khusus karena merupakan candi utama. Sedangkan kelompot candi Brahma dan Wisnu dikerjakan oleh kelompok yang lainnya, atau dikerjakan pada masa dan oleh seniman yang berbeda?

Dugaan lain dapat diutarakan bahwa, dilihat dari ukuran candi Çıwa paling besar dibandingkan dengan kedua candi di sisi kiri-kanannya berkaitan dengan sistem religi. Sistem religi dalam suatu kebudayaan selalu mempunyai ciri-ciri untuk sedapat mungkin memelihara emosi keagamaan itu diantara pengikut-pengikutnya. Dengan demikian emosi keagamaan merupakan unsur penting dalam suatu religi bersama dengan tiga unsur yang lain, yaitu (i) sistem keyakinan; (ii) sistem upacara keagamaan; (iii) suatu umat yang menganut religi itu (Koentjaraningral 1983: 384-385).

Kondisi masyarakat Jawa kuno tidak terlepas dari konsepsi yang hidup pada masa itu. Candi Ciwa dianggap penting dan mempunyai nilai yang 'khusus', sehingga pengerjaan pentatahan relief dikerjakan secara lebih teliti dan serius untuk mencapai hasil yang maksimal. Guna mencapai harapan tersebut, maka dipilihlah seniman yang handal untuk memahatkan cerita yang mengelilingi candi tersebut.

Apakah ada hubungan antara teknik pentatahan dengan tema cerita?, seperti diketahui pada Candi Çiwa dan Brahma (cerita Ramayana) mengisahkan perjalanan seorang bangsawan atau raja, sehingga memerlukan asesoris yang lengkap. Sebaliknya pada Candi Wisnu cerita Kresnayana mengisahkan "perjalanan hidup" Kresna berperan sebagai "manusia yang banyak bergaul dengan lingkungan masyarakat bawah Dalam hal ini kualitas pentatahannya secara berurutan adalah sebagai berikut: Pertama candi Çiwa, kedua Candi Brahma, dan yang ketiga Candi Wisnu. Knususnya pada Candi Brahma karena merupakan kelanjutan dari cerita Ramayana, teknik pentatahan setingkat lebih baik dibandingkan dengan Candi Wisnu 
Sebagal catatan, bahwa studi dan pengamatan yang dilakukan pade relief-relief candi Prambanan perlu dilakukan penelitian yang seksama, guna mengungkap secara holistik baik dari seni pentatahan dan keindahan, arsitektur, skala kepentingan peletakan relief, dan besar kecilnya ukuran perlu ditindak lanjuti pada masa dan kesempatan yang lain.

Kepustakaan

Haryono, Timbul 1977, Kerajean Mejapahit: Mese Sri Rajesanagara Sampai Girindrawarddhana, Paper Dalam Sarasehan oleh Barahmus DIY dan Fakultas Sastra UGM

Ibrahim, Maulana., 1995. Kompleks Candi Prambanan Dari Masa Ke Masa, Ditlinbinjarah, Jakarta.

Koentjaraningrat,1883, Pengantar IImu Antropologi, Aksara Baru, Jakarta.

Murtjipto, dkk.1991. Relief Ramayana Candi Prambanan, Kanisius, Yogyakarta.

Lelono, Hari. T.M.1985/96, Penelitian Pakaien dan Oroanisasi Sosial Pade Mesa Klasik (tahap II). Laporan Hasll Panelltian Arkeologi. Balai Arkeologi Yogyakarta.

Rangkuti. N. (1995). Candi Dan Kontaksnya: Tinjauan Arkoologi-Ruang.

Barkala Arkaologi. 15(3). 37-42. https://doi.org/10.30883/jba.v15i3.668

Kempers, Bernet.1959, Ancient Indonesian Art C.P.A.J. ven der Peet. Amsterdam.

Koesnoen, A,1971, Candl Prambanan Dan Candl-Candl Sekltamyo, Sumur, Bandung. 


\section{Lampiran}

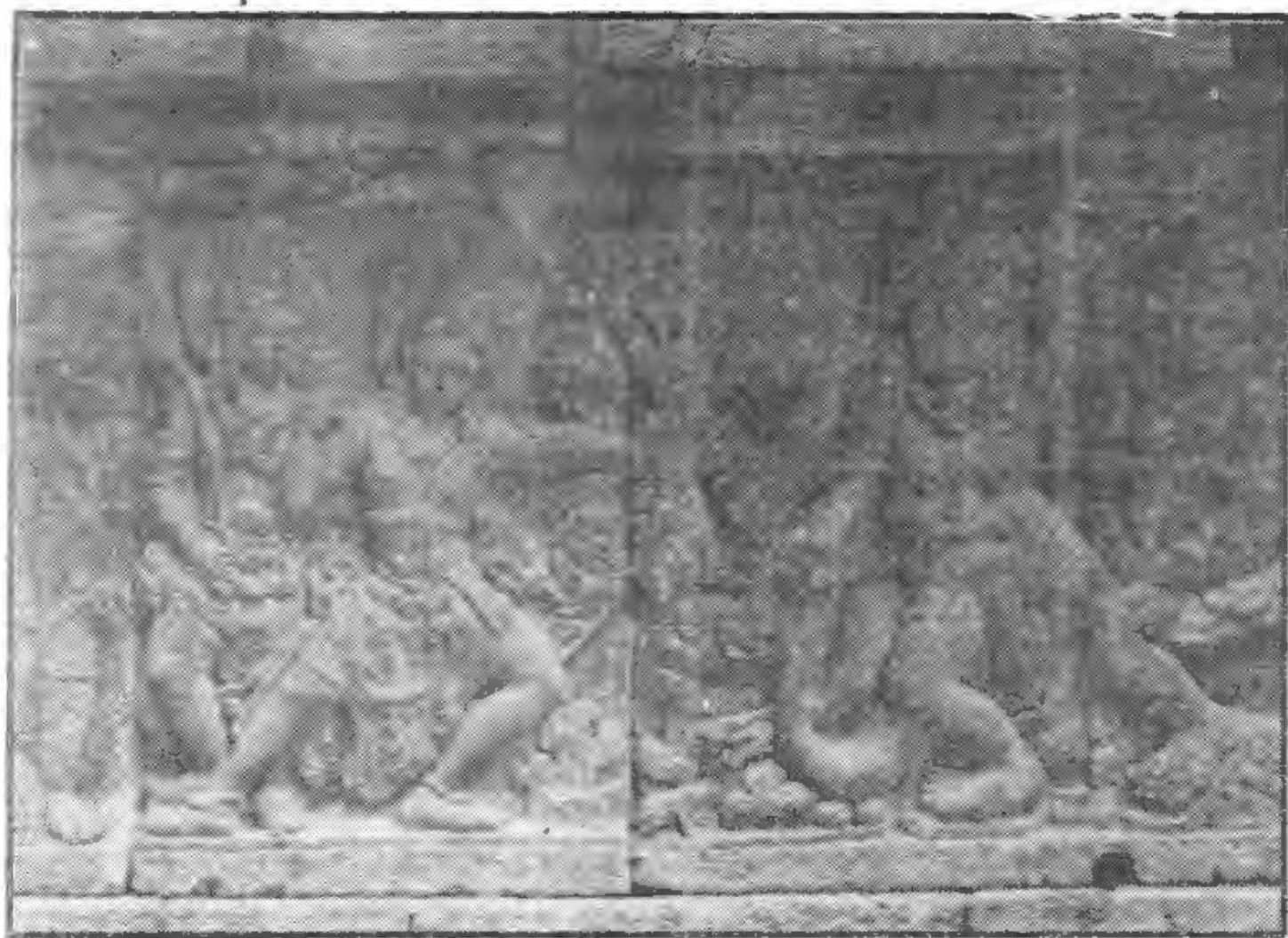

Relief No 13c Candi Ciwa, Rama Dan Laksmana bertempur melawan raksasa Kabandha.

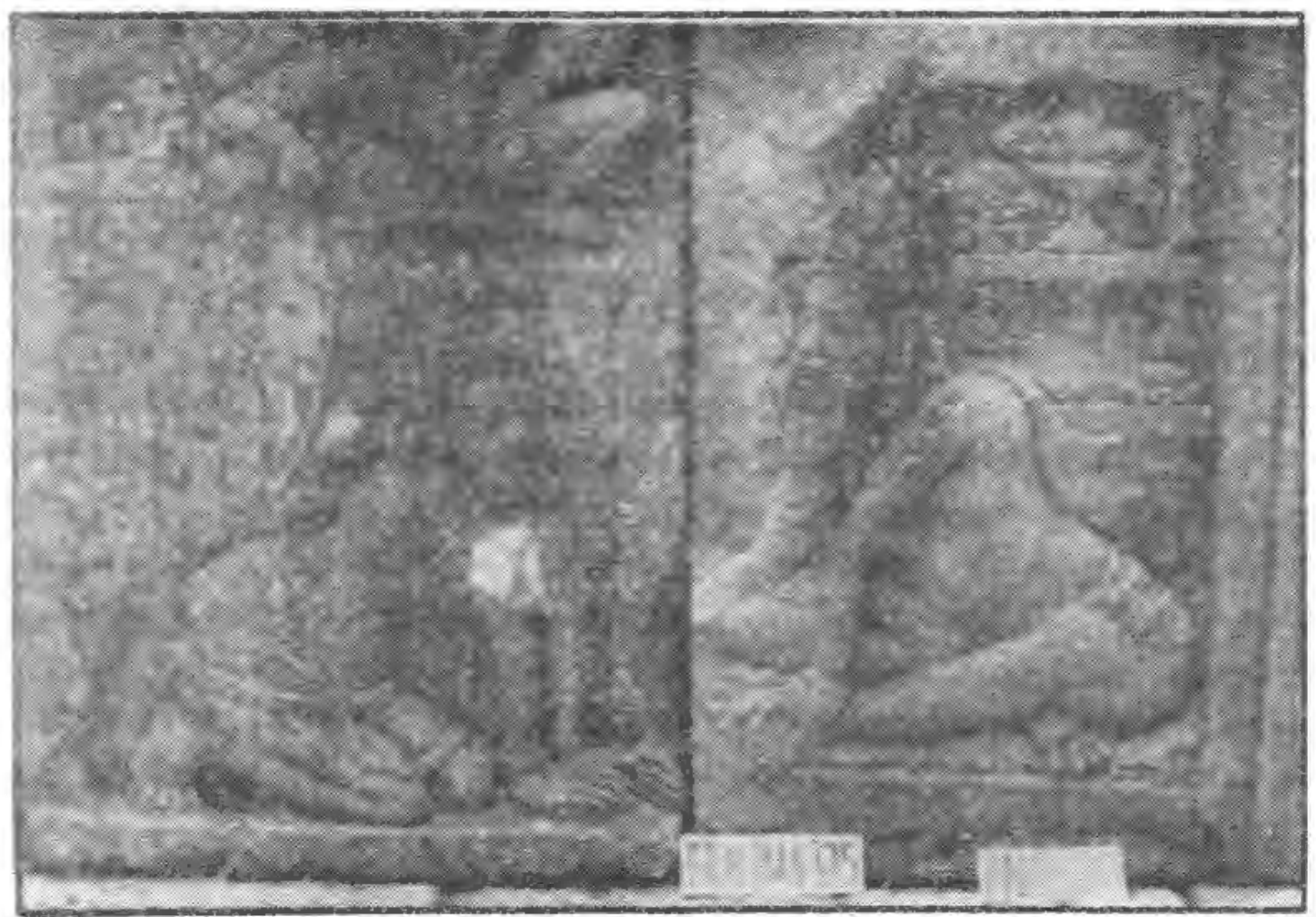

Relief No 20 Candi Brahma, Sinta mengembara dan bersimpuh dihadapan pendeta Mpu Walmiki. 


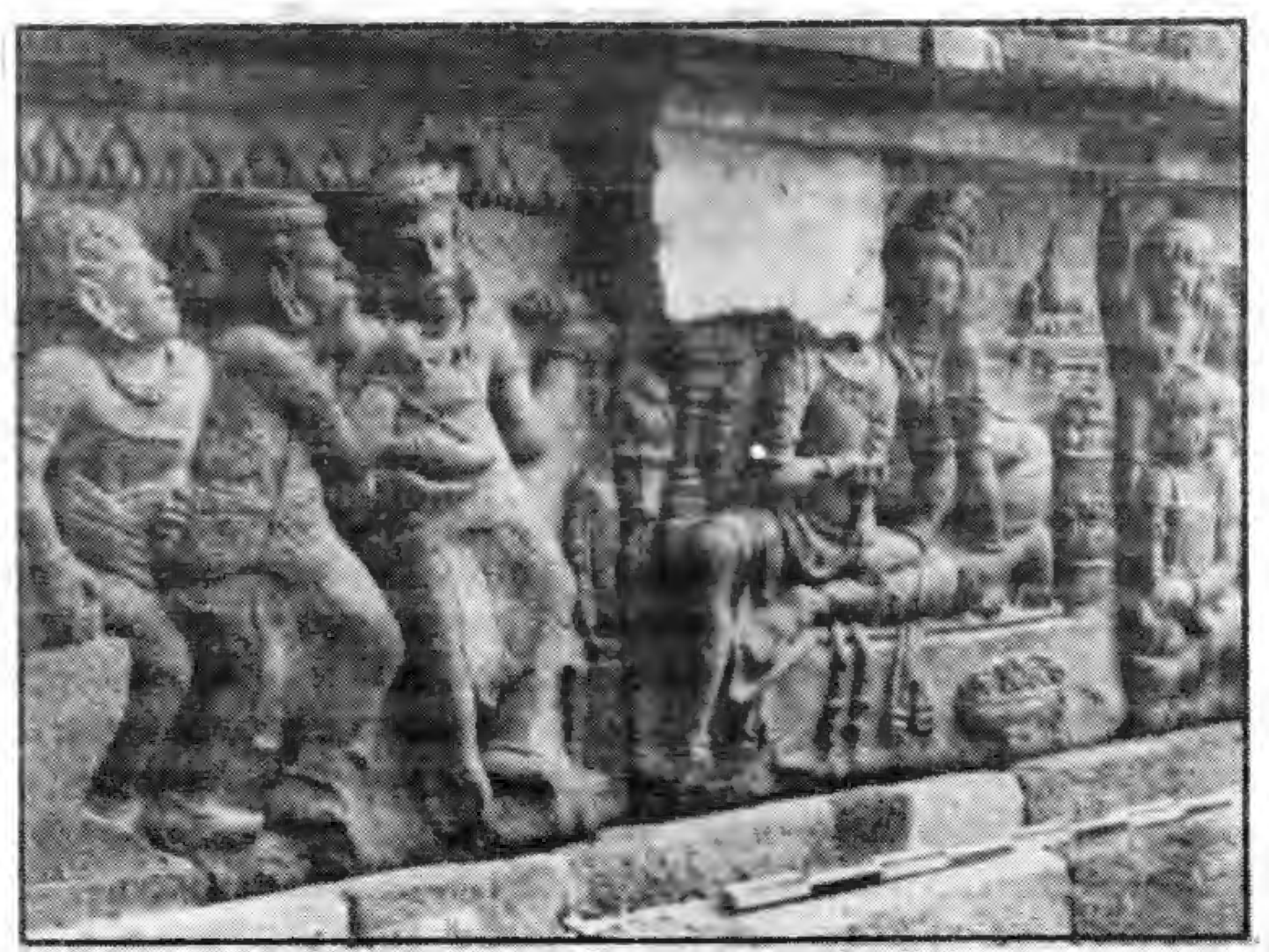

Relief No 16 Candi Wisnu, Kresna duduk dalam sebuah balai 